解説 膜シリーズ 9

\title{
Sulfate Removal from Brine by Using Amphoteric Ion Exchange Resin
}

\author{
Takeshi MATSUSHITA
}

\author{
Planning and Development Department NIPPON RENSUI CO. \\ 3-43-11, Minami-ohtsuka, Toshima-ku, Tokyo 170
}

(Received Sept. 30, 1996)

\section{Introduction}

In the membrane chlor-alkali process, it is essential to control sulfate ion concentration at inlet of electrolytic cell in order to protect membrane against damages. Precipitation by means of barium salt which is currently used for removing sulfate ion has the following problems:

* Barium salt is relatively expensive.

* Barium salt powder is not easy to handle.

* Barium salt is toxic.

* Mud generation needs to be suppressed as it becomes hard to find land to be reclaimed with mud.

Another element to adversely affect membrane performance is chlorate, by-product generated in electrolytic cell. At present, acid is injected to diluted brine in order to lower $\mathrm{pH}$, which leads to decomposition of chlorate. As $\mathrm{pH}$ level needs to be extremely low to trigger chlorate decomposition, however, corrosion of equipment material might be induced.

Nippon Rensui Co. and Mitsubishi Chemical Corp. have jointly developed a chromatograph separation method with amphoteric ion exchange resin featuring innovated configuration for the purpose of primarily removing sulfate. This method is able to remove chlorate together with sulfate when operating conditions are appropriate- ly adjusted. It is an outstanding technique as it does not generate mud and it uses no other chemicals than water in normal operation.

The first commercial plant using this method has been operated at Kurosaki Works of Mitsubishi Chemical Corp. since November 1995. This article presents results of various experimental operations in laboratory which constitute basis for commercial operation.

\section{Outline of DSR01 method}

As shown in Fig. 1, amphoteric ion exchange resin "DIAION DSR01" used in the newly-developed method has both quaternary ammonium group (strong basic anion exchange group) and carboxyl group (weak acidic cation exchange group) in one aromatic group.

Sulfate removal mechanism of the amphoteric ion exchange resin has not yet been fully revealed. Authors speculate as follows:

* Anion exchange group and cation exchange group gets neutralized each other in water to form inner salt.

* When coming in contact with relatively-highconcentration salt such as $\mathrm{NaCl}$, the inner salt interacts both with $\mathrm{Na}^{+}$ion and $\mathrm{Cl}^{-}$ion.

* As the interaction is relatively weak, ions reversibly get eluted even by means of fresh 


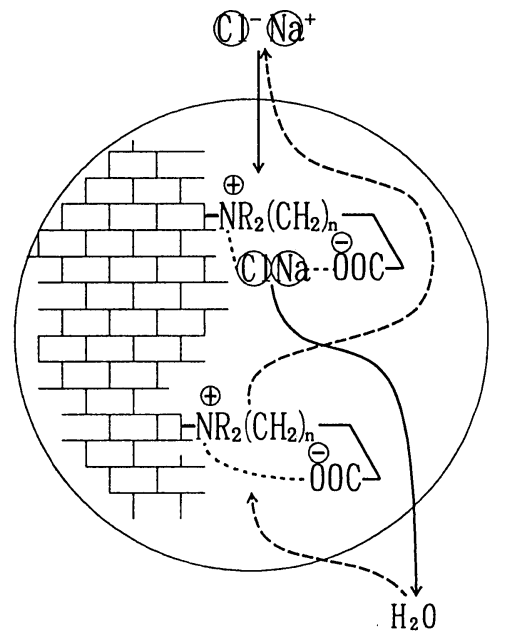

Selectivity $\mathrm{NaClO}_{3}>\mathrm{NaCl}>\mathrm{Na}_{2} \mathrm{SO}_{4}$

Fig. 1 lon-exchange interaction between an electrolyte and an amphoteric resin.

water containing very little salt.

* Selectivity of chloride, sulfate, and chlorate, when contained in brine, on the amphoteric ion exchange resin is as follows:

chlorate $>$ chloride $>$ sulfate

* Due to this selectivity, sulfate gets eluted first to be separated, followed by chloride and chlorate in this order.

\section{Outline of industrial-use separation tower used for sulfate removal}

Sulfate removal system needs to be treated with back washing when suspended solids introduced from brine and eluent are cumulated or when resin bed gets compressed during longterm operation. The separation tower should be designed, therefore, in a way to allow back washing treatment. To be more specific, as shown in Fig. 2, some space needs to be reserved at upper part of the tower.

In separation process, brine is fed through a distributor mounted close to surface of resin bed. The upper space of the tower is filled with water which functions as eluent. The eluent is injected

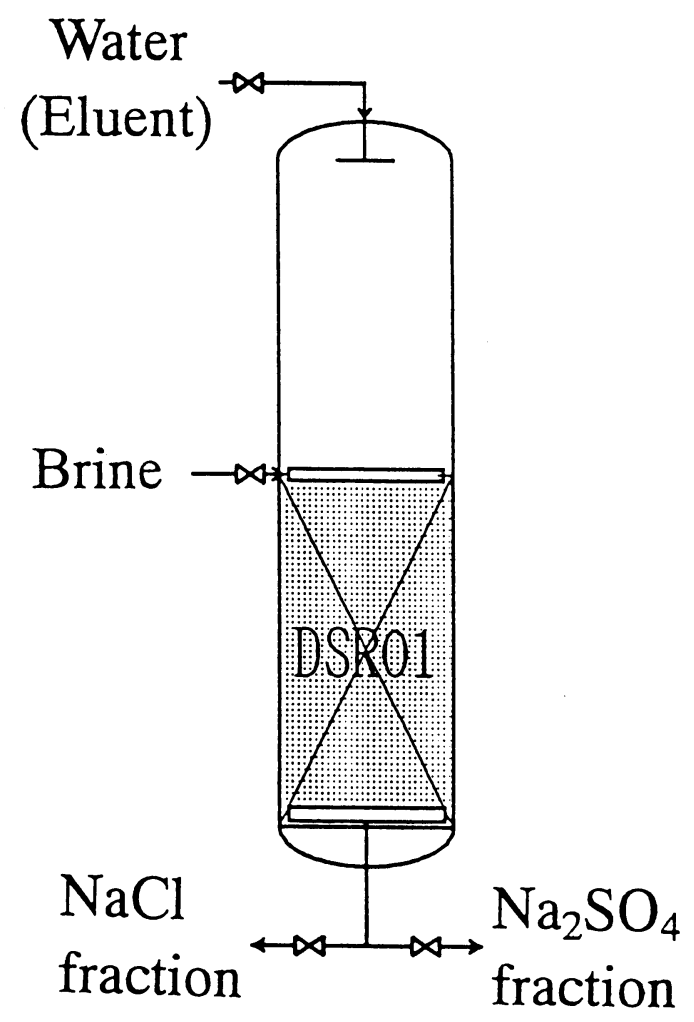

Fig. 2 Schematic of an industrial-scale separation system.

from the top to brine to trigger separation.

\section{Experiment using sample brine containing chloride and sulfate}

\subsection{Experimental}

Fig. 3 shows chemical structure of resin used in the experiment. The resin has styrene-divinylbenzene copolymer as basis and N,N-dimethylglycine as ion exchange group. Average particle size of the resin is $256 \mu \mathrm{m}$, and uniformity is 1.04 .

Since the industrial-use separation tower can not be used for the experiment in a small laboratory, a packed column system is employed instead. A jacket-covered glass column is $20 \mathrm{~mm}$ in inner diameter and $1000 \mathrm{~mm}$ in length. It is filled with DSR01 of $320 \mathrm{~m} l$. Table 1 shows experimental conditions.

Fig. 4 shows an example of chromatogram. Salt concentration in the eluate is monitored with 
<smiles>CCC(CC)c1ccc(CC(CC)c2ccccc2)cc1</smiles>

Fig. 3 Chemical structure of DIAION DSRO1.

$\mathrm{RI}$ detector. What is eluted from when refractive index reaches $0.32 \times 10^{-3} \mathrm{RIU}$ to when it gets to $3.2 \times 10^{-3} \mathrm{RIU}$ is regarded as sulfate fraction. Wtat is eluted after that until when refractive index hits $0.64 \times 10^{-3}$ RIU is regarded as chloride fraction.

\subsection{Experimental result and discussion}

In designing the system, amount of resin should be determined by referring to time required for one-cycle operation.

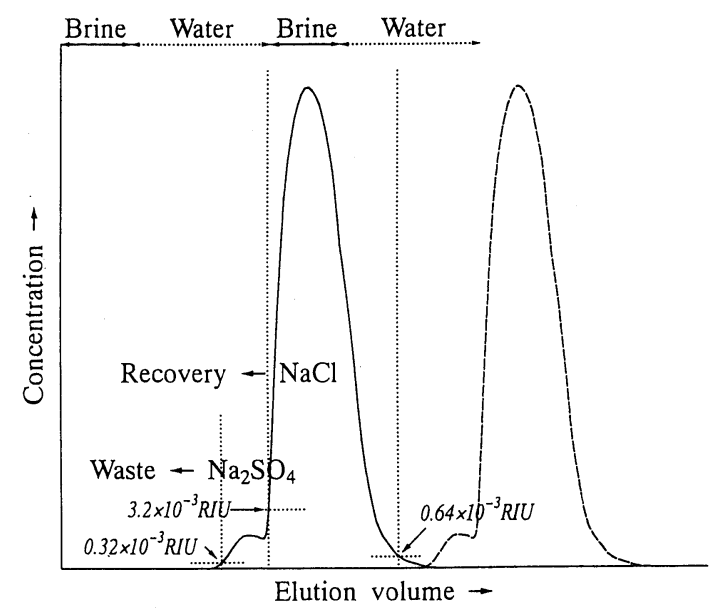

Fig. 4. Typical chromatogram.

Based on experimental results, this Section presents sulfate removal efficiency per unit time per unit resin volume calculated in the following equation:

Table 1 Experimental conditions

\begin{tabular}{ccccc}
\hline $\begin{array}{c}\mathrm{NaCl} \text { conc. } \\
(\mathrm{g} / \mathrm{L})\end{array}$ & $\begin{array}{c}\mathrm{Na}_{2} \mathrm{SO}_{4} \text { conc. } \\
(\mathrm{g} / \mathrm{L})\end{array}$ & $\begin{array}{c}\text { Temperature } \\
\left({ }^{\circ} \mathrm{C}\right)\end{array}$ & $\begin{array}{c}\text { Flow rate } \\
(\mathrm{mL} / \mathrm{h})\end{array}$ & $\begin{array}{c}\text { Feed volume } \\
(\mathrm{mL})\end{array}$ \\
\hline 195 & 7.5 & 60 & 640 & 64 \\
195 & 7.5 & 60 & 640 & 80 \\
195 & 7.5 & 60 & 640 & 96 \\
195 & 7.5 & 60 & 640 & 112 \\
195 & 7.5 & 60 & 960 & 48 \\
195 & 7.5 & 60 & 960 & 64 \\
195 & 7.5 & 60 & 960 & 80 \\
195 & 7.5 & 60 & 960 & 96 \\
195 & 7.5 & 60 & 960 & 112 \\
195 & 7.5 & 60 & 1280 & 48 \\
195 & 7.5 & 60 & 1280 & 64 \\
195 & 7.5 & 60 & 1280 & 80 \\
195 & 7.5 & 60 & 1280 & 96 \\
195 & 7.5 & 60 & 1280 & 112 \\
195 & 7.5 & 60 & 1600 & 48 \\
195 & 7.5 & 60 & 1600 & 64 \\
195 & 7.5 & 60 & 1600 & 80 \\
195 & 7.5 & 60 & 1600 & 96 \\
195 & 7.5 & 60 & 1600 & 96 \\
150 & 7.5 & 60 & 960 & 96 \\
250 & 7.5 & 60 & 960 & 96 \\
195 & 5.5 & 60 & 960 & 96 \\
195 & 9.0 & 60 & 960 &
\end{tabular}




$$
E_{\text {SO4:h }}=\frac{V_{0} \cdot C_{0: S O 4}-V_{c f} \cdot C_{c t: S O 4}}{V_{R} \cdot T}
$$

where:

$\mathrm{E}_{\mathrm{SO} 4 \mathrm{~h}}=$ sulfate removal efficiency

$\left(\mathrm{g}-\mathrm{Na}_{2} \mathrm{SO}_{4} / \mathrm{L}\right.$-resin $\left.\cdot \mathrm{h}\right)$

$\mathrm{V}_{0}=$ amount of feed brine

$\mathrm{V}_{\mathrm{cf}}=$ amount of chloride fraction (L)

$\mathrm{C}_{0: \mathrm{SO} 4}=\mathrm{Na}_{2} \mathrm{SO}_{4}$ concentration in feed brine

$\mathrm{C}_{\text {cf:SO4 }}=\mathrm{Na}_{2} \mathrm{SO}_{4}$ concentration in chloride fraction $(\mathrm{g} / \mathrm{L})$

$\mathrm{V}_{\mathrm{R}}=$ resin volume $(\mathrm{L})$

$\mathrm{T}=$ time of one-cycle operation $(\mathrm{h})$

Fig. 5 shows experimental result. Sulfate removal efficiency is found to increase as space velocity is raised. This result implies that sulfate removal efficiency can be improved by increasing velocity of brine even if resin volume, i.e. size of the system, is limited. Increasing velocity, however, leads to abnormally high pressure loss. Controllability of the system may get deteriorated due to extremely short process time of one-cycle operation. High velocity also accelerates loss

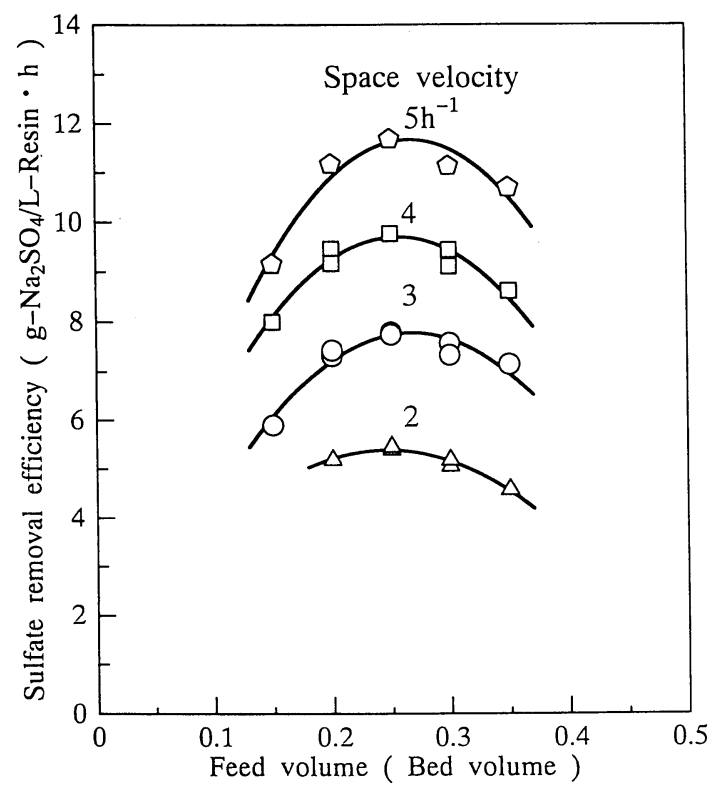

Fig. 5 Effect of brine volume on sulfate removal efficiency. of chloride as chloride removed together with sulfate is increased. Addressing these points, authors have decided that optimum space velocity should be $3-4 \mathrm{~h}^{-1}$. Optimum amount of feed brine is found to be 0.20 to $0.30 \mathrm{BV}$.

Chloride concentration is found to have limited effect as shown in Fig. 6, but sulfate removal efficiency tends to get lower along with increase of chloride concentration. Fig. 7 shows chromatogram with chloride concentration in brine varied. Variation of chloride concentration is only reflect-

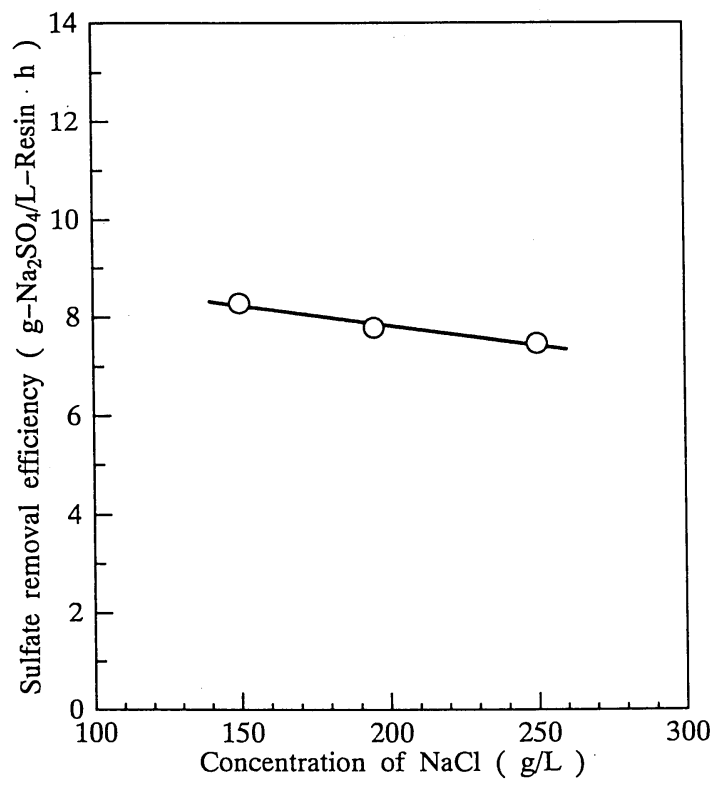

Fig. 6 Effect of $\mathrm{NaCl}$ concentration on sulfate removal efficiency.

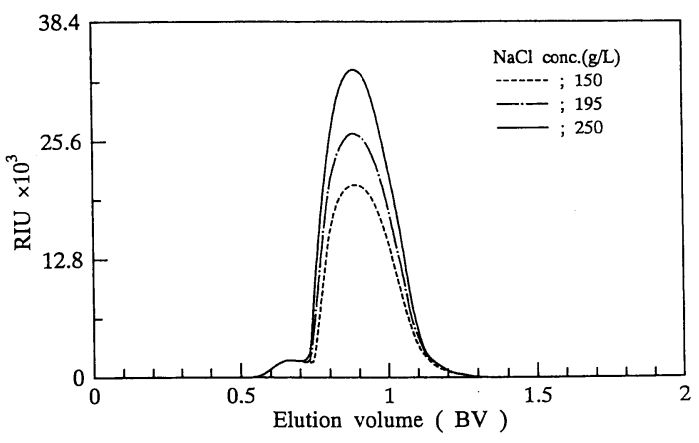

Fig. 7 Effect of $\mathrm{NaCl}$ concentration on elution curve. Feed volume; $0.25 \mathrm{BV}$ $\mathrm{Na}_{2} \mathrm{SO}_{4}$ conc.; $7.5 \mathrm{~g} / \mathrm{L}$ 
ed on chloride concentration peak in chloride fraction, and it does not affect timing to start and complete elution.

Sulfate concentration is found, as shown in Fig. 8, to directly affect sulfate removal efficiency. Along with rise of sulfate concentration, sulfate removal efficiency gets higher. This is because sulfate concentration of sulfate fraction rises in proportion to increase of sulfate concentration in feed brine.

These results indicate sulfate removal process using DSR01 should be applied to diluted brine which is treated in dechlorination process as it features high sulfate concentration and low chloride concentration.

\section{Treatment of brine containing chlorate as well as chloride and sulfate}

Actual brine contains chlorate as well as chloride and sulfate. Chlorate gets eluted, following chloride elution. Fig. 9 shows chromatogram of the entire elution cycle of diluted brine containing $\mathrm{NaCl}$ of $164 \mathrm{~g} / \mathrm{L}, \mathrm{Na}_{2} \mathrm{SO}_{4}$ of $10.1 \mathrm{~g} / \mathrm{L}$, and $\mathrm{NaClO}_{3}$ of $18.1 \mathrm{~g} / \mathrm{L}$. In other words, this is the chromatogram obtained when eluent is kept

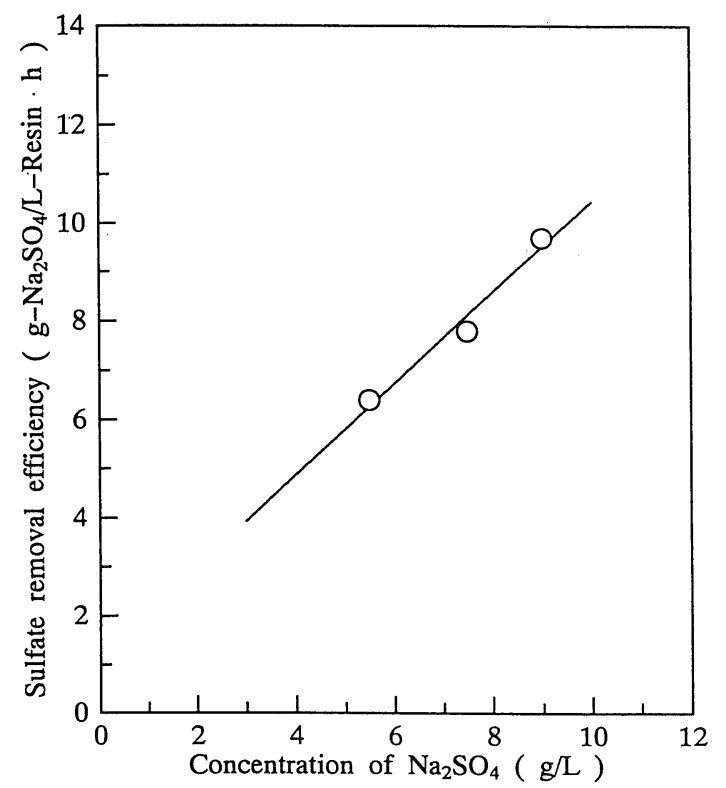

Fig. 8 Effect of $\mathrm{Na}_{2} \mathrm{SO}_{4}$ concentration on sulfate removal efficiency. being injected up to until one elution cycle is fully completed. It is possible to separate all of the three components by letting one elution cycle be fully completed. Compared with separation process targeting only on sulfate, however, time required to complete one-cycle operation gets longer, and amount of resin needs to be increased.

In Fig. 10, chlorate and sulfate are removed simultaneously by starting second round of elu-

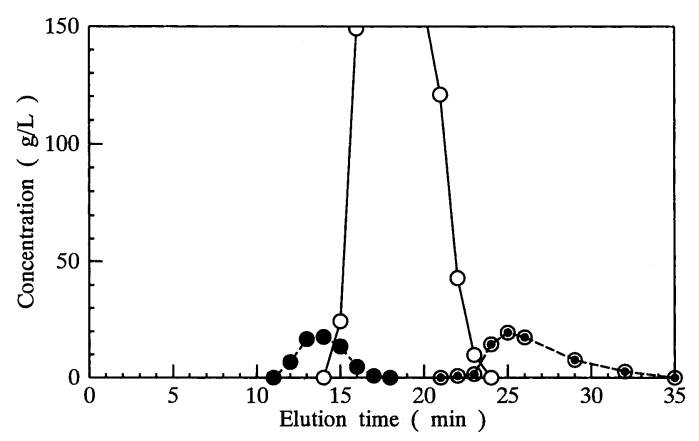

Fig. 9 Single cycle separation of brine containing chloride, sulfate and chlorate.

Bed; $320 \mathrm{~mL}$

Feed; $96 \mathrm{~mL}$ of brine

$\left(\mathrm{NaCl} 163 \mathrm{~g} / \mathrm{L}+\mathrm{Na}_{2} \mathrm{SO}_{4} 10.1 \mathrm{~g} / \mathrm{L}+\mathrm{NaClO}_{3}\right.$ $18.1 \mathrm{~g} / \mathrm{L})$

Flowrate; $960 \mathrm{~mL} / \mathrm{h}$

Temperature; $60^{\circ} \mathrm{C}$

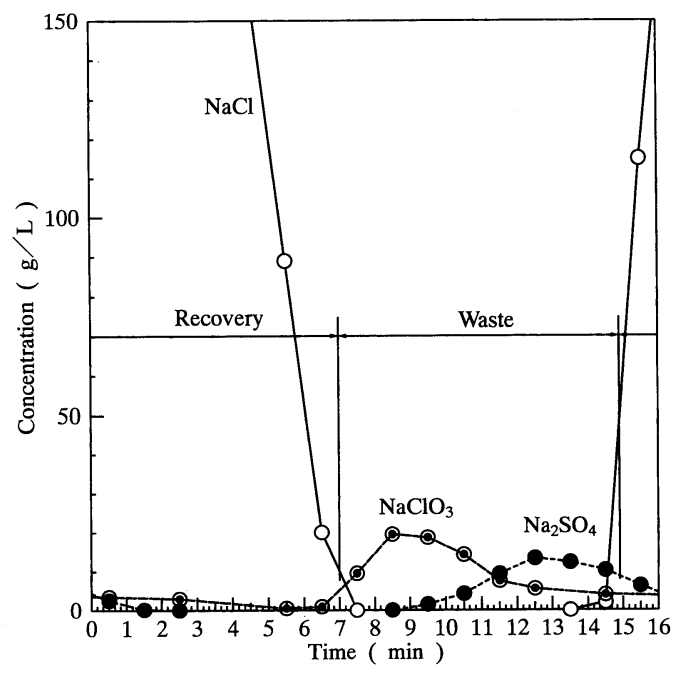

Fig. 10 Multi cycle separation operated to have chlorate peak and sulfate peak overlapped each other. 
Table 2 Results of analysis of each fractions

\begin{tabular}{|c|c|c|c|c|}
\hline & & $\begin{array}{c}\text { Recovery } \\
\text { (NaCl frac.) }\end{array}$ & $\begin{array}{c}\text { Waste- } 1 \\
\left(\mathrm{NaClO}_{3} \text { frac. }\right)\end{array}$ & $\begin{array}{c}\text { Waste-2 } \\
\left(\mathrm{Na}_{2} \mathrm{SO}_{4} \text { frac. }\right)\end{array}$ \\
\hline \multicolumn{2}{|c|}{ Fractionating time } & $\begin{array}{r}0^{\prime} 00^{\prime \prime}-7^{\prime} 00^{\prime \prime} \\
14^{\prime} 55^{\prime \prime}-16^{\prime} 00^{\prime \prime}\end{array}$ & $7^{\prime} 00^{\prime \prime}-10^{\prime} 00^{\prime \prime}$ & $10^{\prime} 00-14^{\prime} 55^{\prime \prime}$ \\
\hline Fraction & $\operatorname{vol}(\mathrm{L} / \mathrm{L}-\mathrm{R} \cdot$ cycle $)$ & 0.404 & 0.15 & 0.246 \\
\hline \multirow[t]{2}{*}{$\mathrm{NaCl}$} & conc. $(\mathrm{g} / \mathrm{L})$ & 121 & 0.67 & 0.31 \\
\hline & recov. $(\%)$ & 100.0 & 0.2 & 0.2 \\
\hline \multirow[t]{2}{*}{$\mathrm{Na}_{2} \mathrm{SO}_{4}$} & conc. $(\mathrm{g} / \mathrm{L})$ & 1.24 & 0.60 & 10.14 \\
\hline & recov. $(\%)$ & 16.5 & 3.0 & 82.3 \\
\hline \multirow[t]{2}{*}{$\mathrm{NaClO}_{3}$} & conc. $(\mathrm{g} / \mathrm{L})$ & 3.00 & 16.15 & 7.33 \\
\hline & recov. $(\%)$ & 22.3 & 44.6 & 33.2 \\
\hline
\end{tabular}

tion before the first one is completed so as to have chlorate peak and sulfate peak overlapped each other. In this case, the peak combining sulfate and chlorate is broader than individual peak obtained in one-cycle operation. This is considered because highly-selective adsorption band of chlorate comes in contact with another adsorption band of sulfate and the two interfere each other.

Table 2 shows amount of component recovered in each fraction which is bordered as shown in Fig. 10. In the actual operation, either Effluent 1 or Effluent 2 in Table 2 contains sulfate fraction and chlorate fraction. According to calculation using Table 2, amount of chlorate removed in one elution cycle is $4.22 \mathrm{~g}-\mathrm{NaClO}_{3} / \mathrm{L}$-resin -cycle. Removal efficiency is found to be $77.8 \%$.

\section{Material balance and cost comparison}

Based on the above experimental results, authors have estimated material balance and running cost.

Weighted average of $\mathrm{NaCl}$ purity and $\mathrm{SO}_{4}$ concentration is calculated by using amount and composition of imported salt. $\mathrm{NaCl}$ purity and $\mathrm{SO}_{4}$ concentration are calculated to be $96.87 \%$ and $0.163 \%$ respectively. Theoretical calculations are based on the assumption that salt featuring purity of $96.87 \%$ of $1.508 \mathrm{t}$ (containing $\mathrm{SO}_{4}$ of 0.2458 $\mathrm{kg}$ ) is mixed with water of $0.4504 \mathrm{t}$ to manufac- ture $\mathrm{NaOH}$ of $1 \mathrm{t}, \mathrm{H}_{2}$ of $0.0252 \mathrm{t}$, and $\mathrm{Cl}_{2}$ of $0.8862 \mathrm{t}$.

The following conditions are also used in calculations:

annual replacement of DSR01: 25\%

(DSR01 is found not to be deteriorated in the life test.)

processing plant operation: 300 days a year daily production of caustic soda: $300 \mathrm{t}$

Fig. 11 shows calculated material balance while Table 3 shows comparison between DSR01 method and other methods in terms of running cost.

Detailed data of chlorate removal have not yet been taken. Supported by the single result mentioned above, authors assume that chlorate removal efficiency is in inverse proportion to chlorate concentration, and calculate chlorate removal efficiency by using the following equation:

$$
\mathrm{E}_{\mathrm{ClO3}: \mathrm{C}}=0.2331 \times 0.8 \times \mathrm{C}_{0: \mathrm{ClO} 3}
$$

where:

$\mathrm{E}_{\mathrm{CIO3}: \mathrm{C}}=$ Chlorate removal efficiency

(g-Chlorate/L-resin·cycle)

$\mathrm{C}_{0: \mathrm{ClO} 3}=$ Chlorate concentration of feed brine

It is found that this method can remove chlorate if chlorate generation during electrolysis can be suppressed below $0.976 \mathrm{~kg}-\mathrm{NaClO}_{3} / \mathrm{m}^{3}$ 
Table 3 Cost comparison

\begin{tabular}{|c|c|c|c|c|c|}
\hline & & $\begin{array}{c}\text { DSR } \\
\text { method }\end{array}$ & $\underset{\text { method }}{\mathrm{BaCl}_{2}}$ & $\begin{array}{l}\mathrm{BaCO}_{3} \\
\text { method }\end{array}$ & $\begin{array}{l}\text { Brine } \\
\text { purge }\end{array}$ \\
\hline \multicolumn{6}{|l|}{ Chemicals; } \\
\hline $\mathrm{BaCl}_{2} \cdot 2 \mathrm{H}_{2} \mathrm{O}$ & $120 ¥ / \mathrm{kg}$ & & 846.48 & & \\
\hline $\mathrm{BaCO}_{3}$ & $120 ¥ / \mathrm{kg}$ & & & 683.76 & \\
\hline $\mathrm{Na}_{2} \mathrm{CO}_{3}$ & $20 ¥ / \mathrm{kg}$ & & & -61.24 & \\
\hline $\mathrm{NaCl}$ & $4 ¥ / \mathrm{kg}$ & & -13.52 & & 434.62 \\
\hline DSR01 & $5,000 ¥ / \mathrm{L}$ & 129.30 & & & \\
\hline (sum) & & $(129.30)$ & $(832.96)$ & $(622.52)$ & $(434.62)$ \\
\hline \multicolumn{6}{|l|}{ Utilities; } \\
\hline Power & $12 ¥ / \mathrm{kWh}$ & 10.52 & & & \\
\hline Water & $30 ¥ / \mathrm{m}^{3}$ & 15.53 & & & 16.41 \\
\hline (sum) & - & $(26.05)$ & & & $(16.41)$ \\
\hline Mud treat. & $10,000 ¥ / \mathrm{t}$ & & 96.25 & 96.25 & \\
\hline \multicolumn{2}{|c|}{ Total running cost $(¥ / \mathrm{t}-\mathrm{Cl})$} & 155.35 & 929.21 & 718.77 & 451.03 \\
\hline
\end{tabular}

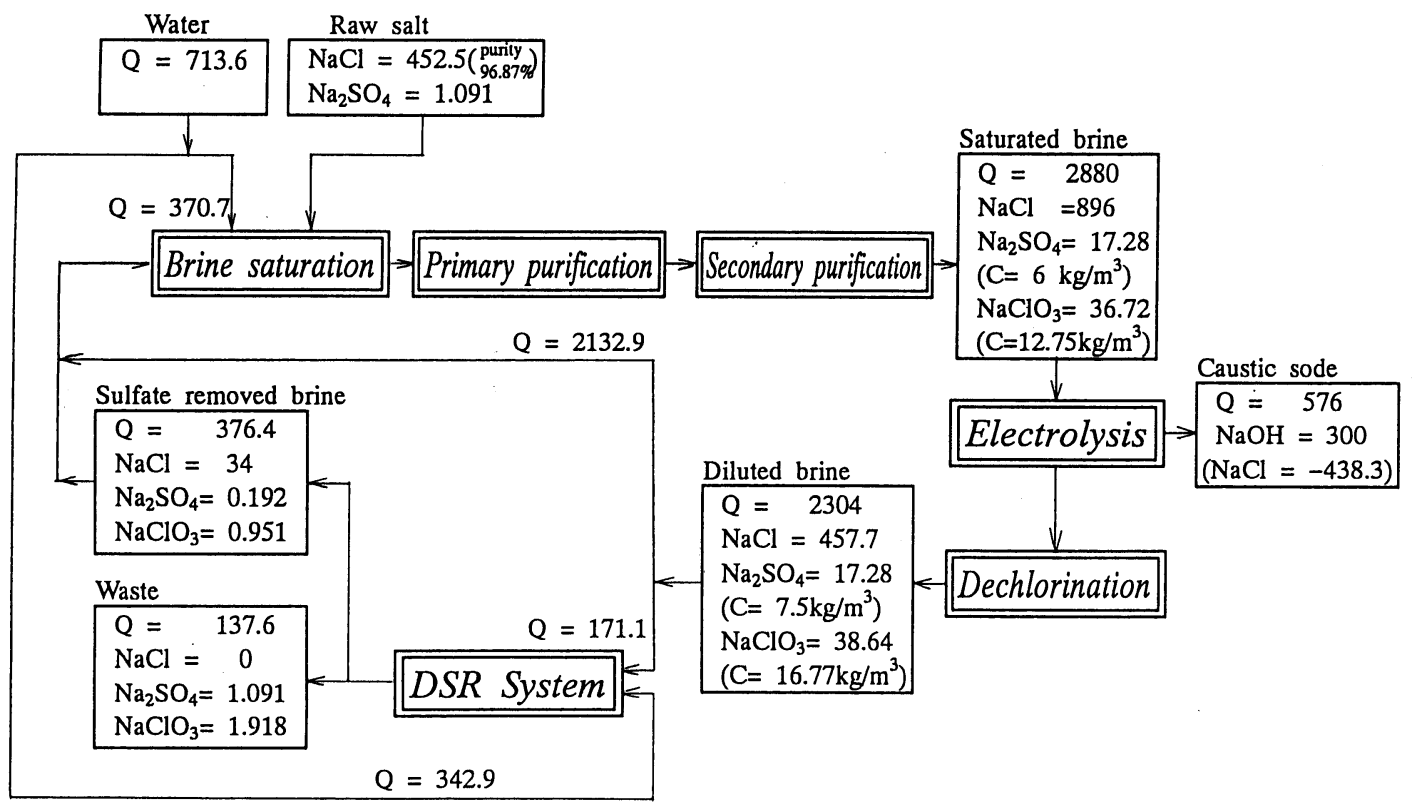

Fig. 11 Material balance.

$\mathrm{Q}$; the flow quantity $\left(\mathrm{m}^{3} / \mathrm{d}\right)$

C; concentration $\left(\mathrm{kg} / \mathrm{m}^{3}\right)$

others; $(\mathrm{t} / \mathrm{d})$

$\left(0.765 \mathrm{~kg}-\mathrm{ClO}_{3} / \mathrm{m}^{3}\right)$ and chlorate concentration at inlet of electrolytic cell is limited to $12.75 \mathrm{~kg} /$ $\mathrm{m}^{3}$.

\section{Points to be noted in designing commercial system}

Fig. 12 outlines process flow of sulfate removal using DSR01 method. 


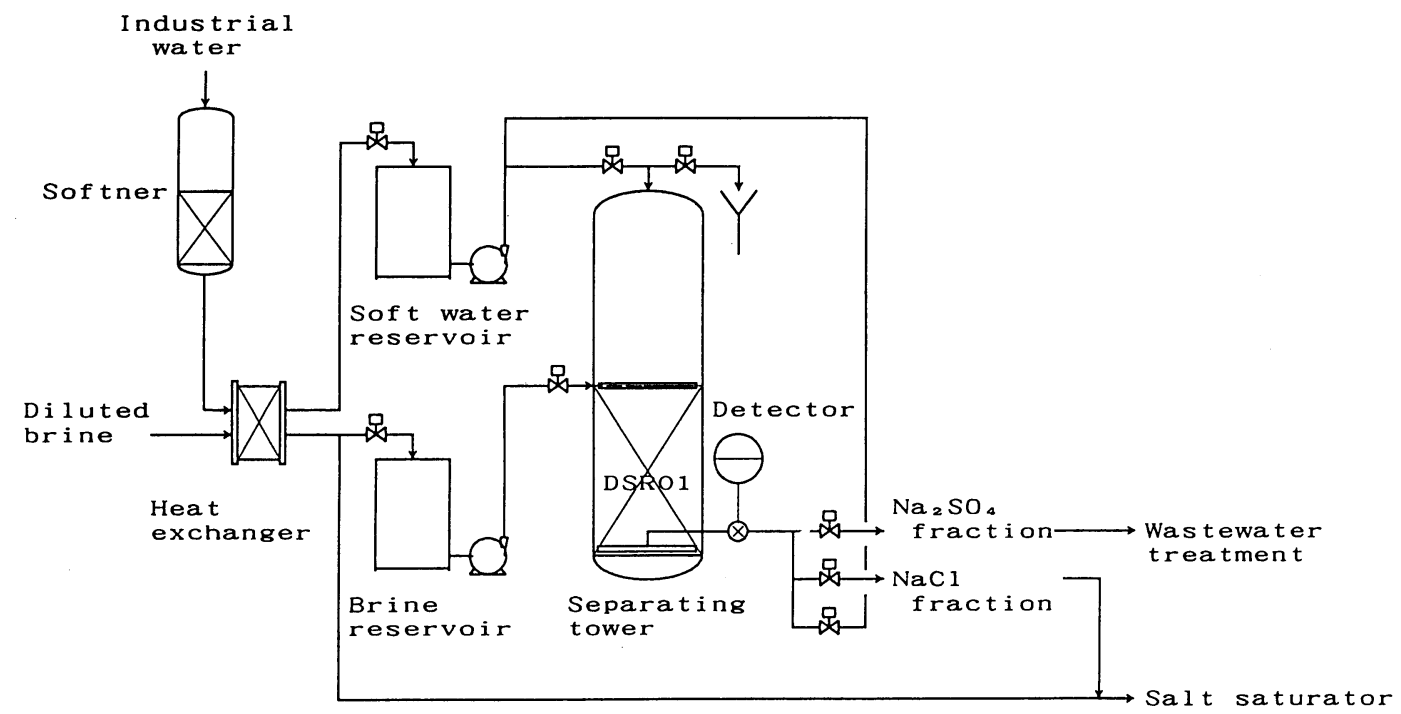

Fig. 12 Schematic process flow of an industrial separation system.

Soft water is used as eluent in order to prevent hard component in industrial water from reacting with bicarbonate ion in industrial water and with caustic alkali in diluted brine. Such reaction leads to precipitation of manganese hydroxide and calcium carbonate in resin bed to clog it.

Rate of this chromatograph method is determined by particle diffusion, and high temperature is preferable. Due to limited heat resistance of resin, however, upper limit of temperature should be $60^{\circ} \mathrm{C}$. It is not recommended to increase temperature of diluted brine and to keep eluent at room temperature. The separation tower made from steel sheet and rubber lining is exposed to too much temperature variation, which damages rubber lining. It is necessary to perform heat exchange between diluted brine and industrial water so as to maintain a certain temperature range.

Majority of running cost required for the chromatograph separation method is cost of resin replenishment. It is necessary to find a way to decrease amount of resin in order to achieve cost reduction. Modification of resin and equipment should be important to further upgrade this method. 


\title{
両性イオン交換樹脂による塩水中の硫酸塩除去
}

\author{
松下 武志 \\ 日本鍊水株式会社 企画開発部 \\ ₹170 東京都豊島区南大塚 3-43-11
}

(1996 年 9 月 30 日受理)

要 旨

イオン交換膜法カセイソーダ製造プロセスに拈いて, 塩水中の硫酸塩除去はバリウム塩沈殿 法が多く採用されているが，マッドの廃棄処理など多くの問題を抱えており，これに代わる方

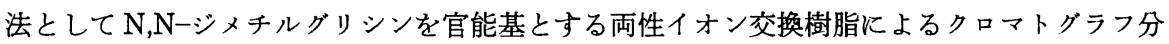
離法を紹介した。この方法は硫酸塩のみならず，電槽で発生する塩素酸塩をも同時に除去で き，しかも通常の運転に拈いては水以外の薬剤を使用しないといら画期的な方法である。実プ ラントは三菱化学(侏黑崎事業所において 1995 年 11 月より稼動中である。 